\title{
Pemanfaatan Teknologi Tepat Guna Berbasis Solar Cell untuk Mengatasi Permasalahan IRT Nelayan Sapeken Kabupaten Sumenep
}

\author{
Iin Hindun ${ }^{1 *}$, M. Mulyono², H. Husamah ${ }^{3}$ \\ 1,2,3 Universitas Muhammadiyah Malang
}

\section{A R T I C L E I N F O}

Article history:

Received 20 May 2019

Received in revised form

10 June 2019

Accepted 30 July 2019

Available online 30 August 2019

\section{Kata Kunci:}

Abon, perahu, Sapeken, solar cell, teknologi tepat guna.

Keywords:

Shredded, boat, Sapeken, solar cell, appropriate technology

\begin{abstract}
A B S T R A K
Artikel ini bertujuan menganalisis implementasi pemanfaatan TTG berbasis solar cell untuk mengatasi permasalahan IRT Nelayan Sapeken. Mitra kegiatan yaitu Dapoer Emmak dan Sapeken Sejahtera. TTG yang diimplementasikan berupa alat pembuat abon dan perahu. Instrumen kegiatan meliputi materi presentasi, produk, alat dokumentasi, buku catatan, dan instrumen evaluasi. Metode pengabdian adalah survey, demonstrasi, dan praktek langsung, dan evaluasi. Data dikumpulkan dengan terlibat langsung dalam aktivitas masyarakat, pengambilan sampel produk dan perekaman dokumen serta kegiatan. Data dianalisis secara deskriptif. Kegiatan dianggap berhasil bila TTG mahir digunakan oleh mitra, persentase keterlibatan dan keaktifan mencapai $\geq 75 \%$, ada peningkatan kuantitas dan kualitas produk/hasil usaha, income meningkat, dan semua tahapan kegiatan terlaksana. Berbagai kegiatan dilakukan pengabdi, yaitu koordinasi dan konsolidasi tim, serta penyamaan persepsi dengan mitra, pendesainan, penyiapan, dan pembuatan, penyerahan TTG, pelatihan, dan pemanfaatan TTG oleh mitra, serta monitoring dan evaluasi. Dpat disimpulkan bahwa kegiatan pengabdian telah dilaksanakan dengan sangat baik, sesuai dengan target yang telah ditetapkan.
\end{abstract}

\section{A B S T R A C T}

This article aims to analyze the implementation of the use of solar cell-based TTG to overcome the IRT problem of Sapeken Fishermen. The activity partners are Dapoer Emmak and Sapeken Sejahtera. The TTG is implemented in the form of shredded and boat makers. Instrument activities include presentation materials, products, documentation tools, notebooks, and evaluation instruments. Service methods are survey, demonstration, and direct practice, and evaluation. Data is collected by being directly involved in community activities, product sampling and document recording and activities. Data were analyzed descriptively. Activities are considered successful if TTG is proficiently used by partners, the percentage of involvement and activity reaches $\geq 75 \%$, there is an increase in the quantity and quality of products / business results, income increases, and all stages of activities are carried out. A variety of activities are carried out, including coordination and team consolidation, as well as equalizing perceptions with partners, designing, preparing, and making, submitting TTG, training, and utilizing TTG by partners, as well as monitoring and evaluation. It was concluded that the community service activities had been carried out very well, in accordance with the targets set.

\footnotetext{
Corresponding author.

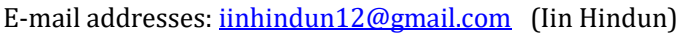




\section{Pendahuluan}

Kecamatan Sapeken merupakan sebuah kecamatan kepulauan di Kabupaten Sumenep, Provinsi Jawa Timur, Indonesia. Wilayah ini terletak di bagian paling ujung atau yang terluar dari Kabupaten Sumenep (Rini, Pratikto, \& Sambodo, 2015; Sukandar et al., 2016; M. A. Sutanto, Riyanto, \& Yuwono, 2013). Penduduk di Kepulauan Sapeken mayoritas adalah keturunan etnies-etnies dari Sulawesi, yaitu bajo, mandar, dan bugis. Bahasa keseharian yang digunakan adalah ketiga Bahasa dari etnies tersebut (Fadhila, 2017; Rahayu, 2019; Satriyati \& Rahayu, 2009). Begitu pula dari aspek mata pencaharian, dimana mayotitas penduduknya adalah nelayan. Secara ekonomi, kondisi mereka tergolong sulit atau tertinggal (Efendi, 2017; Rahman, 2018).

Masyarakat nelayan, terlebih yang mereka hidup di kepulauan-kepulauan terpencil umumnya memiliki kecenderungan tertinggal secara ekonomi atau miskin, baik secara kultural struktural (Agussalim, 2014; Cristianawati, 2017; Inounu, Martindah, Saptati, \& Priyanti, 2007; Rahmat \& Malik, 2015). Banyak faktor yang jadi penyebab kondisi kemiskinan tersebut, misalnya kondisi geografis yang jauh, pasar yang tidak adil, kapitalisme para pemilik modal, (Agussalim, 2014; Hamzah, 2015; LPPM-UNEJ, 2017; Surjanti \& Nuswantara, 2016; Sutrisno, 2012), pendidikan yang rendah, minimnya akses terhadap sarana-prasarana dan modal. kebijakan pemerintah yang tidak pro-rakyat, dan faktor internal masyarakat sendiri (Bappenas, 2016; DPR RI, 2014; Izzaturrahim, Waluti, Rahayuwati, \& Darmadji, 2015; JICA, 2011; KIARA, 2015; Masyhuri, 2013; Prakoso, 2013; Rosni, 2017; Wardhani, Rekyani, \& Indayati, 2010).

Permasalahan masyarakat tersebut membutuhkan perhatian berbagai pihak untuk menyelesaikannya. Sebab bagaimanapun, nelayan dan keluarganya sebagai tokoh utama sektor perikanan memiliki peran strategis guna tersedianya bahan pangan berbasis laut (DPR RI, 2014; Hapsati \& Fuad, 2017; Nurwidodo, Rahardjanto, Husamah, Mas'odi, \& Hidayatullah, 2018; Rahmatullah, 2016). Perhatian tersebut perlu berwujud penyediaan sarana-prasarana atau teknologi, dan yang tidak kalah penting adalah "pengubahan pola berpikir masyarakat" (Abdurrahman, Arifin, \& Harjito, 2008; Agussalim, 2014; Ishak \& Siang, 2013; Mooniarsih, Yacoub, \& Sanjaya, 2017; Napsiah \& Sanityastuti, 2018; Nurwidodo et al., 2018; Prakoso, 2013; Pringgenies, Yudiati, Nuraeni, \& Susilo, 2017; M. Rizal, Wiryawan, Wisudo, Solihin, \& Haluan, 2017; Suteja, Dirgayusa, Widiastuti, \& Putra, 2019; Warnaen, Cangara, \& Bulkis, 2013).

Kegiatan pendampingan dan pemberdayaan perlu diupayakan sebab menjadi penopang penting bagi kehidupan masyarakat, dan sesuai potensi wilayah (Agustin, Sulestiani, \& Widihartanti, 2015; Anonim, 2015b; Ibad, 2017; Triadiyatma, 2016). Pendampingan harus bermanfaat untuk 1) peningkatan kesejahteraan (Anonim, 2015a; Ishak \& Siang, 2013); 2) penciptaan lapangan kerja yang luas; 3) Mendorong kerjasama banyak pihak; 4) Membantu promosi dan pemasaran; dan 5) Membantu sarana, prasarana, dan modal usaha (Adnyani, Sukerti, \& Wisnawa, 2014; Imaniar, 2017; Laksamana, Ro'is, Syahputra, Firdausiyah, \& Reswita, 2017; Nurfadilah, 2016). Pendampingan harus dampak pada berbagai aspek, yaitu menambah pengetahuan masyarakat, manfaat fisik berupa peningkatan kualitas produk, manfaat psikologis berupa interaksi dan semangat (Farid, Wulanditya, \& Puspitaningrum, 2016; Hindradjit, Rianto, \& Arieffiani, 2017).

Sehubungan dengan itu, dalam konteks yang lebih spesifik, kami melaksanakan pengabdian Program Penerapan Teknologi Tepat Guna (PPTTG) yang disponsori oleh Kemenristek Dikti tahun 2019. Mitra yang terlibat dalam PPTTG ini adalah dua kelompok masyarakat, yaitu kelompok Industri Rumah Tangga (Tradisional) Pembuatan Oleh-oleh khas Kepulauan Sapeken bernama "Dapoer Emmak", yang diketuai oleh Ibu Thahira Hudrie dan kelompok nelayan penangkap ikan bernama "Sapeken Sejahtera" dengan ketuanya adala Bapak Husni Mubarak. Kedua kelompok masyarakat tersebut merupakan kelompok masyarakat kepulauan yang menggunakan peralatan sederhana dan dengan keterbatasan teknologi, baik dalam hal pengolahan hasil laut atau pembuatan oleh-oleh khas Kepulauan Sapeken, maupun dalam menangkap ikan khususnya sebagai bahan baku pembuatan berbagai olahan hasil laut. Setelah melakukan identifikasi masyarakat sekitar, observasi selama beberapa kali dalam 3 tahun terakhir, maka diputuskan untuk memilih dua kelompok tersebut dalam program ini.

Mitra pertama adalah IRT Oleh-oleh Khas Sapeken bernama "Dapoer Emmak". Kelompok ini beranggotakan 5 orang, diketuai oleh ibu Thahira Hudrie. Kelompok ini merupakan kelompok industri rumah tangga yang ada di Pagerungan Besar, Sapeken, Sumenep. Cikal-bakalnya adalah binaan CSR Kangean Energy Indonesia. Namun demikian, pembinaannya sangat terbatas, hanya merupakan program "pembangunan semangat untuk memulai", difokuskan pada pendampingan pembuatan berbagai olahan dan pengemasan. Kelompok ini telah menghasilkan beberapa produk, seperti aneka abon, kripik, dan aneka snack olahan rumput laut.

Persoalan Dapoer Emmak, yaitu tidak optimalnya kualitas dan kuantitas produksi, kurang lamanya daya tahan produk yang dihasilkan karena proses produksi yang manual dan sederhana. Sejauh ini belum ditemukan pembuatan abon ikan yang menggunakan mesin, masyarakat masih menggunakan cara 
tradisional. Beberapa produk yang ditemukan di internet juga menunjukka bahwa alat tersebut sepenuhnya menggunakan listrik. Tentu hal ini tidak sesuai dengan potensi di daerah tersebut. Tentu hal ini akan menimbulkan masalah jika proses produksi dilakukan banyak, sedangkan alat/mesin yang membantu tidak ada, atau ada mesin tetapi membutuhkan sumber listrik.

Mitra yang kedua adalah Kelompok Nelayan "Sapeken Sejahtera”. Kelompok itu beranggotakan 6 orang nelayan, diketuai oleh Bapak Husni Mubarak. Kelompok ini beralamat di Desa Pagerungan Kecil Kecamatan Sapeken Kabupaten Sumenep. Permasalahan mitra kedua adalah sarana-prasarana nelayan melaut yang masih sangat sederhana, sehingga mempengaruhi hasil tangkapan.

Oleh karena itu, solusi yang diberikan adalah pembuatan paket peralatan pembuatan abon ikan. Mesin pembuat abon ikan yang akan dirancang dibuat untuk melengkapi kekurangan mesin yang sudah ada. Mesin pembuat abon ikan ini mempunyai kapasitas kerja yang banyak, pengukusan yang cepat dan sesuai standar sehingga tidak mengurangi nilai gizi, pengerjaan pencucian yang banyak dan higienis, pengerjaan penyuiran yang cepat, kontruksi mesin yang lebih nyaman saat melakukan penyuiran, dan pengadukan yang sesuai, sehingga menghasilkan abon yang bercita rasa khas dan kedepannya cocok sebagai oleh-oleh khas Sapeken Sumenep.

Selain itu, untuk mengatasi permasalahan nelayan maka perlu solusi berupa penyediaan perahu yang terintegrasi dengan penggunaan tenaga surya. Para nelayan kecil selayaknya mendapat sokongan untuk meringankan biaya melaut. Salah satunya melalui aplikasi teknologi, terutama yang lebih ramah lingkungan dan relatif murah. Perahu ini juga dilengkapi dengan standar fasilitas pembekuan ikan, keselematan, dan navigasi yang baik. Adanya perahu terintegrasi tenaga surya (solar cell) diharapkan mampu mengurangi biaya pembelian BBM (solar dan bensin), memaksimalkan pencahayaan yang dibutuhkan, dan memaksimalkan kegiatan penangkapan ikan.

Pengabdian ini berorientasi pada pemberdayaan masyarakat. Pendekatan ini bermakna masyarakat berposisi sebagai pelaku dan penerima manfaat dari proses mencari solusi dan meraih hasil kegiatan. Pendekatan ini mensyaratkan dan mendorong terciptanya kemandirian masyarakat, sebagai hasil dari introduksi pengetahuan dan teknologi tepat guna. Tujuan dari artikel ini adalah menganalisis implementasi pemanfaatan teknologi tepat guna berbasis solar cell untuk mengatasi permasalahan IRT Nelayan Sapeken Kabupaten Sumenep.

\section{Metode}

Metode Terdapat beberapa pihak yang terlibat dalam PPTTG ini. Beberapa pihak tersebut, antara lain (1) tim pengusul PPTTG yang merancang teknologi tepat guna untuk mengatasi permasalahan, kegiatan dilakukan bersama dengan beberapa dosen yang pakar di bidang permesinan, pakar pemberdayaan masyarakat, dan tim pengabdian terdahulu; (2) Direktorat Penelitian dan Pengabdian pada Masyarakat (DP2M) Universitas Muhammadiyah Malang sebagai regulator dan pemonitor internal; (3) Bengkel Mesin Karya Brawijaya yang beralamat di Jl. Sidomakmur 76 A, Mulyoagung, Dau, Malang yang dilibatkan dalam pemroduksian alat; (4) Produsen penyedia solar cell dan peralatan lain yang dibutuhkan; (5) Tukang pembuat perahu di Sapeken Sumenep; dan (6) mitra PPTTG, yaitu Ibu Thahira Hudrie (Dapoer Emmak) dan Bapak Husni Mubarak (Sapeken Sejahtera) sebagai pengguna teknologi tepat guna.

Partisipasi mitra dalam pelaksanaan program yang diusulkan, yaitu (1) Mitra melibatkan diri dan berkomitmen penuh dalam program penerapan teknologi tepat guna ini. (2) Mitra menyediakan ruangan produksi sesuai dengan kebutuhan yang diperlukan untuk instalasi teknologi yang diaplikasikan. (3) Mitra bersedia menggunakan dan merawat peralatan yang telah diberikan. (4) Mitra bersedia mengikuti pelatihan penggunaan alat dan teknologi yang diberikan, perawatan peralatan produksi dan melakukan reparasi sendiri (perawatan mandiri) atas permasalahan yang mungkin timbul terhadap teknologi yang diinstalasikan. (5) Mitra berkomitmen mengambangkan diri dan usaha yang ada dan pada gilirannya akan melibatkan banyak pihak (padat karya).

Instrumen atau alat dan bahan yang digunakan dalam pengabdian ini, yaitu berbagai materi presentasi (saat pelatihan), contoh produk, alat dokumentasi, buku catatan, dan instrument evaluasi. Berbagai teknologi tepat guna disediakaan. Seperangkat peralatan/mesin pembuatan abon, yaitu pemasak (autoclave presto), pengaduk/penggoreng stainless steel, dan mesin peniris minyak abon) yang terintegrasi dengan solar cell. Teknologi yang kedua adalah adanya perahu yang terintegrasi dengan solar cell. Metode yang digunakan dalam pengabdian ini adalah survey, demonstrasi, dan praktek langsung, dan evaluasi. Data dikumpulkan dengan cara terlibat langsung dalam aktivitas masyarakat, pengambilan sampel produk, perekaman dokumen, dan penyebaran angket respon masyarakat mitra. Data yang dianalisis secara deskriptif. 
Evaluasi dan monitoring dilakukan sejak tahapan persiapan implementasi, implementasi awal, pertengahan hingga akhir implementasi untuk melihat kendala yang ditemukan dan upaya mengatasinya serta untuk mendorong terwujudnya keberlanjutan program. Keberlanjutan program akan ditempuh dengan pengembangan upaya penguatan usaha produksi (empowering) dan perluasan usaha (advocation) melalui pengembangan jalur pemasaran dan diversifikasi produk jenis dan bentuk usaha yang dilakukan oleh nelayan. Kegiatan pengabdian dianggap telah berhasil bila alat telah selesai dibuat dan digunakan oleh mitra secara mahir, persentase keterlibatan dan keaktifan masyarakat mencapai $\geq 75 \%$, ada peningkatan kuantitas dan kualitas produk/hasil usaha dibandingkan sebelum dilaksanakannya pengabdian, aspek income yang diperoleh mitra dibandingkan sebelum dilaksanakannya pengabdian, dan semua tahapan kegiatan yang telah direncakanan dapat terlaksana.

\section{Hasil dan pembahasan}

Berdasarkan Tahapan yang akan dilaksanakan dalam program TTG ini adalah sebagai berikut :

\section{Koordinasi dan Konsolidasi Tim, serta Penyamaan Persepsi dengan Mitra}

Tim melakukan koordinasi dan konsolidasi internal untuk menyamakan persepsi antar tim pengabdian, merencanakan kegiatan yang akan dilakukan, dan melakukan pembagian tugas. Kegiatan ini terlaksana dengan baik. Hasil dan luaran kegiatan ini adalah kesepakatan, catatan/notulen kegiatan, dan presensi kegiatan. Tim membagi tugas dalah hal kegiatan (a) identifikasi permasalahan masyarakat yang membutuhkan bantuan teknologi tepat guna, (b) analisis solusi permasalahan serta pencarian alternatif teknologi tepat guna, (c) Pendesainan teknologi tepat guna yang telah disepakati, (d) Perancangan Mesin dan Perahu, (e) Pendampingan masyarakat, dan (f) Publikasi.

Tim juga melakukan penyamaan persepsi dengan mitra. Dalam kegiatan dilakukan (a) pengidentifikasian jenis usaha dan potensi mitra dan wilayah sekitar, (b) pemetaan permasalahan dan alternatif solusi yang dapat ditawarkan melalui kegiatan observasi dan wawancara, dan (c) analisis alternatif solusi untuk memecahkan persoalan-persoalan mitra dengan memanfaatkan teknologi tepat guna. Hasil kegiatan ini berupa adanya informasi bahwa peralatan yang digunakan oleh kelompok ini adalah bersifat sederhana dan manual, sepenuhnya menggunakan peralatan yang ada di dapur, belum tersentuh oleh teknologi yang tepat dan memadai. Hal ini menyebabkan produksi sangat lambat, kurang higienis, dan kualitas yang masih rendah. Karena peralatan yang sederhana tersebut, maka jumlah produksi masih sangat kecil, terbatas, dan dengan daya tahan yang belum sesuai. Jumlah produksi hanya 50 buah per item selama sebulan. Itupun sepenuhnya hanya memenuhi pesanan beberapa karyawan perusahaan yang akan pulang kampong ke Jawa. Peralatan dan teknologi masih menjadi kendala, karena kendala ketersediaan listrik. Di Sapeken, listrik hanya menyala di malam hari, itupun hanya selama 6 jam (dari pukul 18.00-24.00).

Di sisi lain, jenis abon yang dihasilkan masih sangat terbatas, yaitu abon ikan tongkol dan terkadang abon kepiting. Hal ini karena pembuatan abon memerlukan waktu relatif lama. Daging ikan harus dihaluskan terlebih dahulu dengan sehalus-halusnya. Dalam pembuatan abon ikan biasa, ikan yang sudah direbus akan dihaluskan dengan cara memasukannya ke dalam blender. Setelah ikan dihaluskan, ikan digoreng dan diberi bumbu sampai ikan berubah bentuk menjadi kering dalam bentuk serbuk/tepung yang berwarna kecoklatan. Kegiatan seperti itu dapat dilakukan apabila kapasitas jumlah abon yang akan kita buat sedikit. Akan menimbulkan masalah apabila ikan yang akan dijadikan abon dalam jumlah yang sangat besar.

Terkait dengan mitra kedua (Sapeken Sejahtera), sebagaimana umumnya di Indonesia, mayoritas penduduk Sapeken bermata pencaharian nelayan tangkap. Sebagaimana permasalahan nelayan Indonesia pada umumnya, kemiskinan menjadi permasalahan utama nelayan di Sapeken. Ketika melaut, daerah tangkap atau cakupan wilayah edar mereka sangat terbatas karena perahu yang kecil, mesin tenaga kecil, akses penerangan dan navigasi yang lemah, dan pengawetan tangkapan yang tidak maksimal (hanya beberapa jam). Keterbatasan ini menyebabkan nhasil tangkapan yang sedikit dan tidak mampu memenuhi permintaan masyarakat, terlebih memenuhi permintaan industri rumah tangga olahan hasil laut (misalnya Dapoer Emmak).

Kepulauan Sapeken sebenarnya memiliki potensi perikanan yang masih terbuka untuk investasi dan meningkatkan kesejahteraan masyarakatnya karena dianugerahi kondisi geografis. Hampir seluruh masyarakat (nelayan) yang ada di kepulauan Sapeken merupakan tipe nelayan kecil, seperti yang kita ketahui bahwa nelayan kecil merupakan nelayan yang pekerjaannya menangkap ikan hanya pada musimmusim tertentu (musiman). Selain itu nelayan tersebut hanya bekerja paruh waktu. Hal ini terjadi karena peralatan melaut yang mereka miliki masih sangat terbatas, teknologi sederhana, tidak efektif dan efisien. 
Padahal sebagian besar masyarakat memang memutuskan menjadi nelayan "hakiki', yaitu pekerjaan satusatunya yang dijadikan gantungan hidup adalah dengan cara melaut.

Selain itu nelayan yang ada sangat kurang akan pengetahuan terkait bagaimana caranya agar mendapatkan hasil yang melimpah dari laut tanpa merusak keanekaragaman hayati dan biota lau yang ada. Oleh karena itu kehidupan nelayan dan masyarakat pesisir harus mendapat perhatian secara luas, terlebih pemerintah dan akademisi. Kondisi kehidupan nelayan dan masyarakat pesisir (termasuk dalam hal ini juga adalah pembudidaya) harus mendapat perhatian secara luas, terlebih pemerintah dan akademisi. Nelayan harus didampingi dan diberikan pengembangan, khususnya meningkatkan pemahaman mereka sehingga kreatif dan inovatif untuk memaksimalkan potensi di sekitar secara bijak dan berkesinambungan, mendapatkan hasil laut yang (maksimal).

\section{Pendesainan teknologi tepat guna, penyiapan, dan pembuatan/perakitan}

Pendesainan TTG paket mesin pembuatan abon dilakukan oleh tim bersama dengan pihak bengkel. Hal yang dipertimbangkan adalah bahan, peralatan, metode dan perakitan, dan gambaran proses kerja. Berdasarkan desain tersebut, tim bersama pihak bengkel melakukan kegiatan penyiapan dan pengadaan (pembuatan) teknologi tepat guna. Tim Bersama pihak bengkel selanjutnya melakukan proses pembuatan/perakitan.

Khusus untuk Perahu Nelayan, kegiatan berupa (a) Menginventarisasi alat dan bahan dan proses serta cara produksi kelompok masyarakat mitra. (b) Mendesain perahu yang sesuai dengan data dan kebutuhan mitra (terintegrasi tenaga surya). (c) Membuat perahu. (d) Memasang instalasi (mesin, tenaga surya, dan lain-lain. (e) Mengujicoba perahu yang telah dibuat.

\section{Penyerahan TTG, pelatihan, dan pemanfaatan teknologi oleh mitra}

TTG telah selesai dibuat/dirakit, selanjutnya diserahkan kepada mitra. Mitra diberikan pelatihan bagaimana menggunakan atau memanfaatkannya. Adapun rancangan teknologi, yaitu (a) Mesin Presto dengan spesifikasi: kapasitas $10 \mathrm{~kg} /$ proses, sumber api berupa burner high pressure, material berupa plat SS, Rangka berupa pipa besi, dan dimensi total adalah $45 \times 45 \times 70 \mathrm{~cm}$. (b) Mesin Penggorengan Abon dengan spesifikasi: kapasitas $10 \mathrm{~kg} /$ proses, material tabung berupa plat SS, rangka berupa pipa MS, penggerak berupa dinamo $1 \mathrm{hp} / 0.75 \mathrm{kw}$, dan dimensi total adalah 50 × 80 × $90 \mathrm{~cm}$. (c) Mesin peniris minyak: kapasitas $5 \mathrm{~kg} /$ proses, material tabung berupa plat SS, rangka berupa pipa MS, penggerak berupa Dinamo $1 / 2 \mathrm{hp} / 0.37 \mathrm{kw}$, dan dimensi total adalah $35 \times 35 \times 50 \mathrm{~cm}$. TTG tersebut seperti yang tersaji pada Gambar 1.

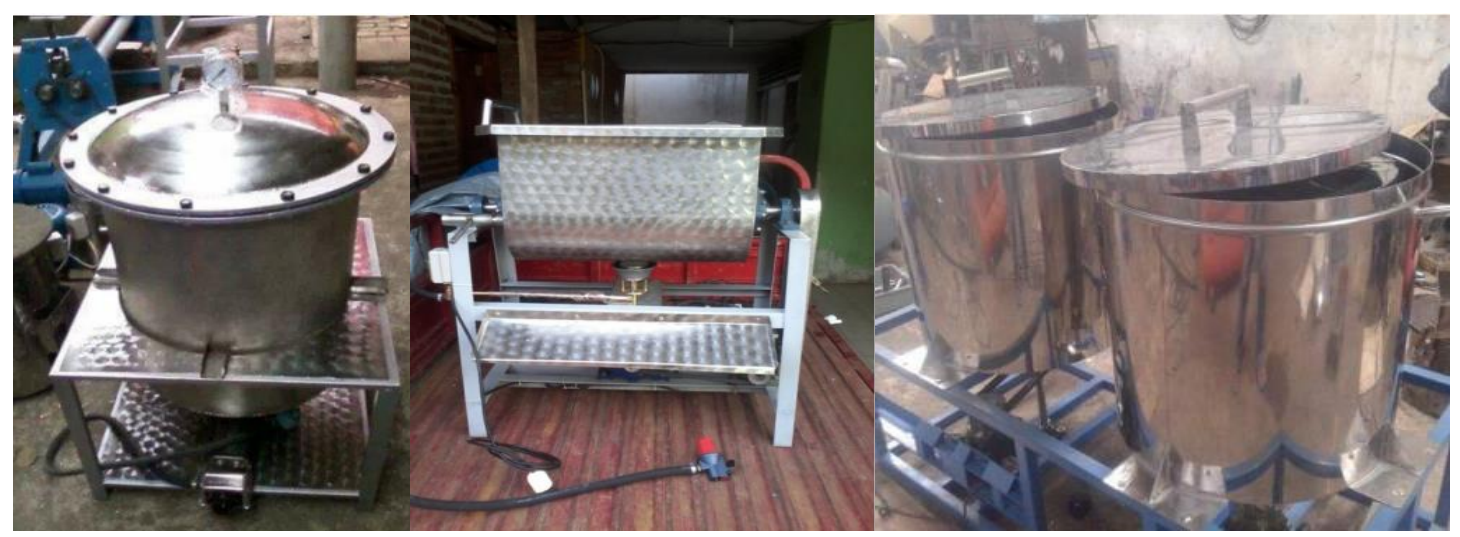

Gambar 1. TTG paket mesin pembuat abon

Adapun deskripsi kerja /proses TTG yang telah diberikan yaitu semua bahan mesin terbuat dari plat stainless steel, khusus untuk produksi makanan (food grade). Bak pembilas berfungsi untuk membilas ikan dalam jumlah yang besar, sehingga bahan baku lebih higienis. Mesin pengukus (mesin presto) berfungsi untuk mengukus ikan sampai pada ukuran kematangan yang dikehendaki sehingga ikan lebih mudah disuir (dilenhkapi dengan indicator suhu). Setelah ikan disuir maka akan memasuki proses pencampuran dengan alat mixer yang menjadi satu dengan mesin pengaduk/penggorengan. Setelah bumbu tercampur dengan daging maka langsung akan digoreng/diaduk karena mesin ini dilengkapi dengan pengaduk otomatis. Bahan akan dibolak-balik secara otomatis. Mesin juga dilengkapi dengan burner LPG lengkap dengan selang dan regulatornya. Alat dilengkapi dengan indikator suhu untuk mengatur panas sesuai dengan seharusnya dan menghindari gagal produksi karena hangus. Selanjutnya 
ada pula alat spinner yang dirancang khusus untuk meniriskan minyak dengan ukuran kasa yang lebih halus, agar abon tidak ikut terbuang dan minyak benar-benar terpisah dari abon. Mesin berkapasitas 25 kg setap 1 kali produksi. Mesin menggunakan motor listrik yang dapat digerakkan pula menggunakan tenaga surya (solar cell).

Sementara itu, TTG berikutnya adalah perahu. Perahu ini dirancang dapat digunakan oleh nelayan untuk mencari ikan di daerah fishing ground, siang dan malam hari, memiliki alat navigasi yang lumayan baik, memiliki tenaga surya sehingga membantu nelayan dalam kaitannya sebagai sumber listrik. Perahu ini diharapkan dapat memudahkan nelayan untuk menangkap ikan, menjual hasi tangkap, dan menyediakan bahan baku secara memadai bagi industri rumah tangga aneka olahan hasil laut. Adapun spesifikasi perahu nelayan terintegrasi tenaga surya, yaitu berukuran 3GT, panjang keseluruhan 7 meter, panjang garis air 5 meter, lebar terbesar 2,5 meter, tinggi sampai geladak 2 meter, tinggi sarat 1 meter. Adapun spesifikasi tenaga surya adalah terdiri atas modul/panel surya (Photovoltaic), Battery Charging Controller, batterai/accu, inverter (Konverter DC ke DC), kabel, dan lampu LED. Perahu telah diberikan kepada mitra dan telah diadakan pendampingan penggunaan alat (tenaga surya) dan pengoperasian perahu. Selain itu dilakukan pula pendampingan produksi dan pemaksimalan fungsi perahu dan kualitas dan pendampingan pemasaran hasil produksi. Adapun perahu yang telah diserahkan ke mitra seperti pada Gambar 2.

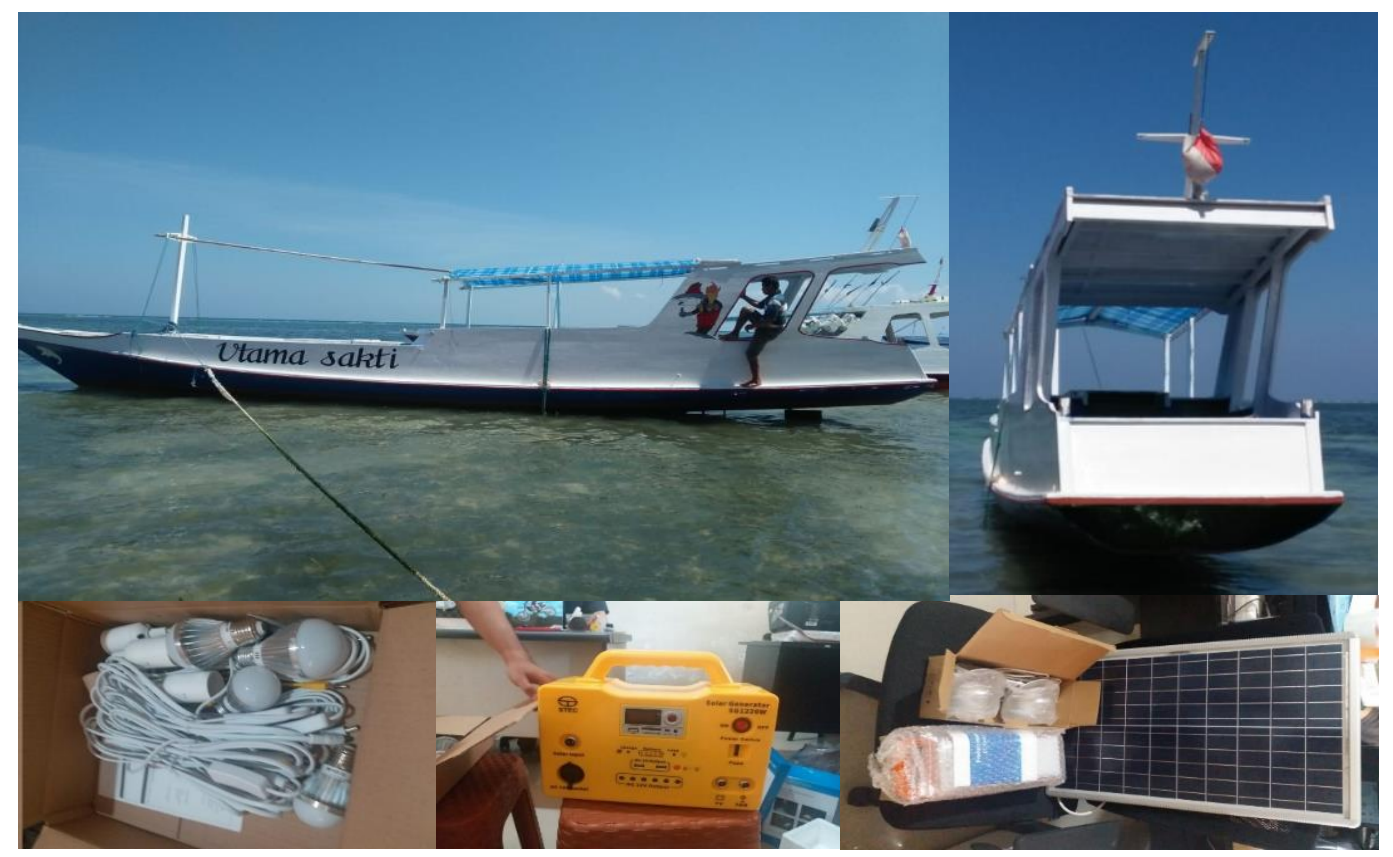

Gambar 2. TTG berupa perahu/kapal terintegrasi solar cell

Khusus untuk Dapoer Emmak, tim juga melakukan pendampingan terkait dengan manajemen usaha dan pengurusan Sertifkat Pangan Industri Rumah Tangga (P-IRT). Tim melakukan penggalian informasi dan konsultasi mengenai syarat-syarat/mekanisme pengajuan P-IRT ke Dinas Kesehatan Kabupaten Sumenep. Dalam diskusi bersama dengan staf/petugas Dinkes Sumenep, didapatkan informasi bahwa pengusul harus mengisi blanko usulan dan memastikan semua persyaratan terpenuhi. Bersama dengan mitra, tim juga telah melengkapi berbagai persyaratan pengajuan P-IRT di Dinas Kesehatan Kabupaten Sumenep, dengan pendampingan khusus oleh staf yaitu Saiful Bahri. Produk abon dan beberapa produk lainnya telah memiliki P-IRT sehingga aman dan dapat dipasarkan.

Tim juga melakukan pendampingan pengemasan, membantu mendesain kemasan dan menyediakan alat pres/sealing machine. Tim pun berupaya memberikan penguatan semangat kepada mitra. Berbagai permasalahan yang dihadapi oleh mitra selama ini menyebabkan menurunnya semangat mereka. Oleh karena itu pendampingan, pemantauan secara berkala dan komunikasi yang terus berlanjut akan terus dilakukan. Tim mengundang mitra/petani untuk mencari pengalaman baru di Malang, kunjungan ke tempat oleh-oleh, dan pembuat kemasan. Tim juga memberikan masukan, bersama-sama mencari jalan keluar, dan memotivasi mereka untuk tetap semangat dalam menjalankan usaha. 


\section{Monitoring dan evaluasi}

Tim melakkan monitoring dan evaluasi terhadap penggunaan TTG yang telah diberikan kepada mitra. Fokus monitoring dan evaluasi adalah pada kepastian diterimanya semua TTG oleh mitra, aspek peningkatan keterampilan mitra dalam menggunakan TTG, peningkatan kualitas dan kuantitas produk, dan aspek income yang diperoleh mitra. Hasil monitoring dan evaluasi menunjukkan bahwa TTG telah selesai $100 \%$ dan telah digunakan, 100\% mitra mahir menggunakan TTG, persentase keterlibatan dan keaktifan masyarakat mencapai $100 \%$, ada peningkatan kuantitas produk/hasil usaha dibandingkan sebelum dilaksanakannya pengabdian sebesar 80\%, aspek income yang diperoleh mitra dibandingkan sebelum dilaksanakannya pengabdian mengalami peningkatan sebesar 200\%, dan semua tahapan kegiatan yang telah direncakanan dapat terlaksana (100\%). Gambaran poduk dan hasil yang diperoleh mitra, seperti pada Gambar 3.

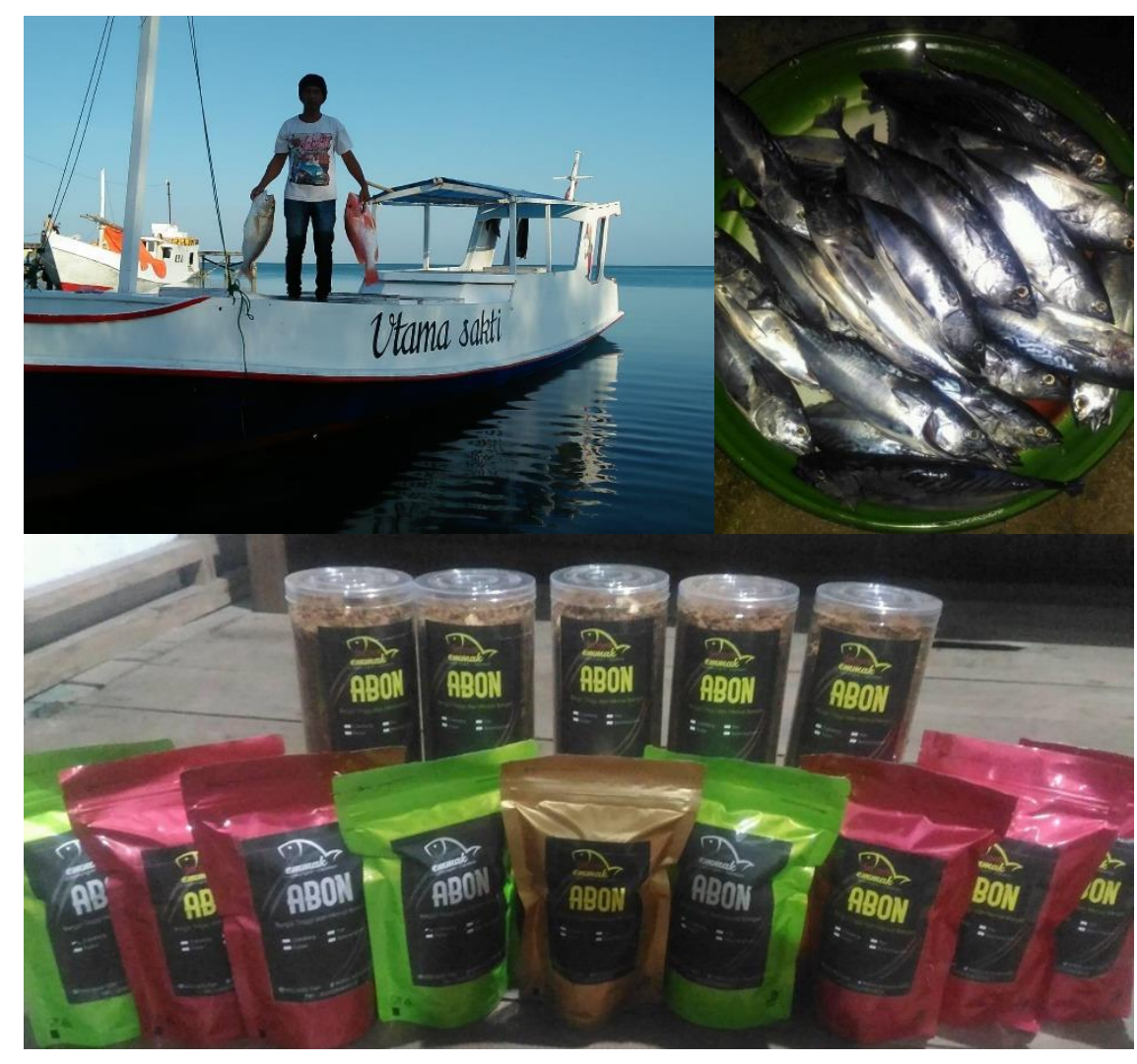

Gambar 3. Hasil dan produk mitra PPTTG (mitra 1ikan hasil tangkapan

Implementasi kegiatan PPTTG dimulai dengan melakukan koordinasi dan konsolidasi internal sebagai upaya penyamaan persepsi, baik antar tim pengabdian maupun dengan mitra dan pihak yang dianggap memiliki dalam suksesnya kegiatan. Setelah tanda tangan kontrak dan tersedianya dana perlu dilakukan koordinasi dengan tim dan mitra. Koordinasi bertujuan untuk mengatur jadwal kegiatan yang sudah disusun supaya sesuai target yang ditetapkan (Ady, 2019; Prastiwi, Sumartono, \& Huda, 2017). Koordinasi dan konsolidasi berguna untuk mengidentifikasi program-program baru dan menciptakan hubungan dan koordinasi dengan pemangku kepentingan masyarakat lainnya (Maleka et al., 2007). Kegiatan ini juga menjadi momentum penjelasan mengenai rencana garis besar langkah-langkah untuk penetapan tujuan, taktik, dan penilaian untuk mengatasi berbagai hal yang penting dan kemungkinan berkembang ke depannya (World Health Organization, 2017).

Komunikasi dengan masyarakat kepulauan/nelayan dan pesisir memang sangat diperlukan. Hal ini sangat penting mengingat proses-proses komunikasi pembangunan belum berlangsung simultan, dan nelayan masih dihadapkan pada persoalan klasik seperti hasil tangkapan yang bervariasi, keterbatasan akses pada sumber-sumber permodalan, pasar, dan program penyuluhan yang belum berjalan sesuai harapan (Amanah, 2010). Selain itu, kesepakatan dan penetapan norma-norma kolektif di era otonomi daerah harus disosialisasikan dengan baik kepada masyarakat nelayan agar mereka memiliki cara pandang yang sama (Witarsa, 2015). 
Dalam hubungannya dengan pengembangan masyarakat pesisir dan nelayan, ada korelasi positif antara kompetensi komunikasi yang dimiliki oleh penyuluh (tim pengabdi) terhadap perilaku masyarakat. Bagaimanapun, faktor keterisoliran dan kompetensi komunikasi, strategi komunikasi mereka sela ini akan sangat berpengaruh terhadap efektifitas komunikasi. Oleh karena itu, pendekatan komunikasi pembangunan partisipatif perlu dikembangkan untuk mengembangkan masyarakat di tingkat bawah (Hasyim \& Ohoiwutun, 2017).

Tim juga melakukan pendesainan TTG, mempersiapkan, dan melakukan pembuatan atau perakitan alat. Menurut Laliyo, Salim, dan Pomalato (2014) perencanaan model didasarkan pada urutan kegiatan pembelajaran yang dirancang sesuai dengan kebutuhan belajar masyarakat untuk proses memberdayakan; dan sengaja dikondisikan sebagai pengalaman belajar; agar masyarakat memiliki pengetahuan dan ketrampilan dalam memanfaatkan teknologi untuk peningkatan kesejahteraannya.

Pendesainan perlu memperhatikan aspek ketelitian dan keterulangan (repeatability) dari pengerjaan serta berkaitan dengan human factor (A. Sutanto, Effiandi, \& Alfian, 2014). Setelah bahan baku disiapkan maka hal selanjutnya yang dilaksanakan adalah menyiapkan gambar desain yang digunakan sebagai pedoman dalam membuat alat. Adapaun proses yang biasa dilakukan adalah pemotongan bahan, pengerolan plat, perakitan dan pengelasan, dan menghaluskan hasil las dan finishing (Sabarudin, Suyatno, \& Su'i, 2017). Perancangan dapat melibatkan beberapa pihak, mulai dari akademisi hingga profesional dalam bidang perangcangan alat. Rancangan alat ditargetkan untuk mendapatkan alat yang efektif dan efisien baik dalam perancangan maupun pemanfaatannya oleh masyarakat (Suhendar, Ramdhan, \& Sudarma, 2019).

Khusus untuk pembuatan perahu, bentuk desain perahu dapat dilakukan bersama-sama dengan mitra (kelompok nelayan). Desain perahu dirancang sesuai dengan kondisi laut/perairan dan jenis perahu yang selama ini digunakan dan mengikut sertakan kearifan lokal masyarakat setempat. Dalam pembuatan perahu perlu adanya pemeriksaan seluruh permukaan perahu dan pengecetan yang dilakukan secara manual. Selanjutnya dilakukan tahapan pengujian dan evaluasi perahu yang meliputi kenyamanan menggunakan perahu, kekuatan perahu, kesesuaian terhadap adat dan budaya setempat, dan tingkat ekonomis produksi perahu (Susanto, 2017). Pembuatan perahu dapat dilakukan dengan metode rancang bangun dan metode pendampingan. Adanya perahu bertujuan untuk mengefektifkan kinerja nelayan, sehingga dapat menghasilkan tangkapan ikan lebih banyak lagi dan meningkatkan nilai jual ikan (Siburian \& Batubara, 2017). Kegiatan ini diharapkan dapat meningkatkan kuantitas dan kualitas produk yang dihasilkan (Anam \& Susilo, 2018; Paryanto, Ardian, \& Rahmawaty, 2012).

Tahapan berikutnya yang dilakukan tim adalah Penyerahan TTG, pelatihan, dan pemanfaatan teknologi oleh mitra. Pola penyerahan alat dilakukan dengan sistem satu alat oleh satu kelompok sebagai bagian dari pembelajaran bersama. Pendampingan penggunaan alat dan perawatan ini ini dilakukan secara berkala, baik secara langsung ke lokasi maupun lewat komunikasi menggunakan sosial media (Suhendar et al., 2019).

Kebijakan pemanfaatan TTG dalam bentukan regulasi telah diatur dalam Keputusan Menteri Dalam Negeri Otonomi Daerah No. 4 Tahun 2001 Tentang Penerapan TTG, disebutkan bahwa TTG dimanfaatkan untuk: (a) Meningkatkan kemampuan pengetahuan dan keterampilan masyarakat dalam menggunakan TTG untuk peningkatan kapasitas dan mutu produksi. (b) Meningkatkan pelayanan informasi dan membantu masyarakat untuk mendapatkan TTG yang dibutuhkan (c) Meningkatkan nilai tambah bagi kegiatan ekonomi masyarakat (d) Meningkatkan daya saing produk unggulan daerah. Penerapan TTG dapat secara umum diartikan sebagai kegiatan yang menyebabkan teknologi itu berfungsi untuk tujuantujuan yang telah di rancang dan untuk sasaran atau kelompok sasaran yang telah direncanakan. Dalam pengertian penerapan seperti itu maka berfungsinya teknologi ini terikat pada tempat dan lingkungannya (Gunawan, 2014).

Tujuan pengembangan suatu teknologi pada dasarnya adalah untuk menjawab kebutuhankebutuhan, baik yang telah nyata, ataupun yang dirasakan dan diinginkan adanya, dan bahkan yang diantisipasi akan diinginkan (Munaf, Suseno, Janu, \& Badar, 2008). Implementasi TTG harus dilandasi oleh asumsi berpikir bahwa induksi teknologi di suatu wilayah semestinya berdampak pada perbaikan hidup masyarakat. Agar induksi TTG tersebut memiliki dampak keberdayaan masyarakat, maka implementasi TTG harus disesuaikan dengan potensi sumberdaya yang ada di wilayah itu, serta kebutuhan masyarakat (Laliyo et al., 2014).

Pelatihan adalah pemberian ketrampilan sesuai kebutuhan yang berkaitan dengan pekerjaan melalui proses pendidikan jangka pendek dengan tahapan yang sistematis. Pelatihan diberikan terkait dengan ketrampilan dan kemampuan yang dibutuhkan dengan adanya pelatihan akan memperbaiki kemampuan melalui peningkatan ketrampilan operasional (Andarwati, Subiyantoro, \& Subadyo, 2018). Melalui proses pendampingan dapat pula dilakukan berbagai pelatihan pengelolaan usaha (produksi dan manajemen), pemasaran, dan motivasi untk melakukan inovasi. Juga dilaksanakan pendampingan dan 
fasilitasi pemasaran produk, melalui pengembangan media pemasaran online baik malalui website, instragram maupun social media lainnya (Anam \& Susilo, 2018; Siburian \& Batubara, 2017).

Ikan sebagai komoditi utama di sub sektor perikanan merupakan salah satu bahanpangan yang kaya gizi. Ikan dapat diolah menjadi produk olahan, salah satunya adalah abon. Salah satu produk abon ikan merupakan produk olahan yang sudah cukup dikenal luas oleh masyarakat (S. Rizal, 2018; S.Politon, Kassa, \& Effendy, 2018). Pendampingan dan pemberian informasi diharapkan dapat menambah pengetahuan yang tepat untuk penanganan ikan segar dan permasalahannya (Pandit, 2016), menjadi olahan abon. Abon ikan merupakan salah satu hasil olahan dari ikan. Usaha pengolahan abon ikan ini dikategorikan ke dalam agroindustri dan kebanyakan usaha ini dilakukan oleh usaha kecil atau menengah yang tergolong dalam industri rumah tangga dan industri pengolahan (Amir, 2008).

\section{Simpulan dan saran}

Kegiatan pengabdian Program Penerapan Teknologi Tepat Guna (PPTTG) telah dilaksanakan dengan sangat baik, sesuai dengan target yang telah ditetapkan. Berbagai kegiatan dilakukan pengabdi, yaitu (1) koordinasi dan konsolidasi tim, serta penyamaan persepsi dengan mitra, (2) pendesainan teknologi tepat guna, penyiapan, dan pembuatan/perakitan, (3) penyerahan TTG, pelatihan, dan pemanfaatan teknologi oleh mitra, dan (4) Monitoring dan evaluasi. Kegiatan pengabdian PPTTG ini bermanfaat bagi mitra, berupa peningkatan keterampilan, semangat, kuantitas dan kualitas produksi, serta peningkatan penghasilan (income). Berdasarkan hal tersebut, ke depannya kegiatan pengabdian dengan tema atau isu terkait yang bersifat pengembangan masyarakat/daerah tertinggal perlu terus digalakkan dan didukung oleh banyak pihak.

Pengabdian Merupakan Skim Program Penerapan Teknologi Tepat Guna (Ppttg) Yang Didanai Oleh Kemenristekdikti Tahun 2019 Dan. Oleh Karena Itu Kami Menyampaikan Terima Kasih Kepada Kemenristekdikti Dan Dppm Umm. Terima Kasih Pula Kepada Para Mitra, Yaitu Pihak Dapoer Emmak Dan Sapeken Sejahtera Atas Kerjasaama Yang Baik.

\section{Daftar Rujukan}

Abdurrahman, A., Arifin, S., \& Harjito, D. A. (2008). Model kebijakan pemberdayaan nelayan Bantul ditinjau dari perspektif ekonomi dan hukum. Jurnal Fenomena, 6(1), 1-19.

Adnyani, N. K. S., Sukerti, N. W., \& Wisnawa, I. G. Y. (2014). IbM Kelompok wanita nelayan Tianyar Timur. Singaraja.

Ady, S. U. (2019). Mengubah paradigma saving society menjadi investment society (peran serta wanita dalam meningkatkan ekonomi keluarga melalui investasi di Bursa Efek Indonesia): Laporan akhir pengabdian pada masyarakat. Surabaya.

Agussalim, A. (2014). Pemberdayaan, upaya meretas kemiskinan masyarakat nelayan. Ambon: BPPP Ambon.

Agustin, T. I., Sulestiani, A., \& Widihartanti, T. (2015). Pemberdayaan masyarakat pesisir melalui pendampingan produksi menuju standarisasi produk di Kelurahan Kedung Cowek-Kenjeran, Surabaya-Jawa Timur. In A. Subianto (Ed.), Prosiding Semiloka Nasional Pemberdayaan Masyarakat Pesisir dalam Rangka Ekonomi Biru (pp. 115-123). Banyuwangi: HAPPI Pusat.

Amanah, S. (2010). Peran komunikasi pembangunan dalam pemberdayaan masyarakat pesisir. Jurnal Komunikasi Pembangunan, 8(1), 1-19. https://doi.org/10.21580/icj.2019.4.1.3530

Amir, R. A. (2008). Strategi pengembangan usaha abon ikan di kub hurip mandiri kecamatan cisolok kabupaten sukabumi. Program Studi Manajemen Agribisnis, Fakultas Pertanian, Institut Pertanian.

Anam, A. K., \& Susilo, E. (2018). Peningkatan produktivitas dan manajemen usaha pada pengrajin anyaman rotan melalui implementasi teknologi tepat guna. Jurnal Pengabdian Dan Pemberdayaan Masyarakat, 2(2), 185-191.

Andarwati, M., Subiyantoro, E., \& Subadyo, T. (2018). Pengaruh pelatihan dan penerapan teknologi tepat guna (TTG) terhadap keberdayaan pengrajin batik tulis ramah lingkungan. BRILIANT: Jurnal Riset 
Dan Konseptual, 3(3), 280-286.

Anonim. (2015a). Profil bisnis usaha mikro, kecil dan menengah (UMKM). Jakarta: Bank Indonesia dan LPPI. Anonim. (2015b). Tumbuh bersama masyarakat. Jakarta: PT Donggi Senoro.

Bappenas. (2016). Kajian strategi industrialisasi perikanan untuk mendukung pembangunan ekonomi wilayah. (BAPPENAS, Ed.). Jakarta.

Cristianawati. (2017). Tradisi masyarakat nelayan Rawa Pening Kelurahan Bejalen Kecamatan Ambarawa Kabupaten Semarang. Sabda, 12(2), 155-160.

DPR RI. (2014). Naskah Akademik dan RUU tentang Perlindungan dan Pemberdayaan Nelayan, Pembudi daya Ikan, dan Petambak Garam, 2013.

Efendi, M. (2017). Implementasi pasal 13 peraturan pemerintah nomor 19 tahun 1999 terhadap ekploitasi sumber daya hayati laut (Studi di Kepulauan Sapeken Kabupaten Sumenep). Fakultas Hukum Universitas Muhammadiyah Malang. Retrieved from http://eprints.umm.ac.id/37759/1/jiptummpp-gdl-maksyarefe-49992-1-pendahul-n.pdf

Fadhila, M. (2017). Pengaruh modernisasi terhadap kearifan lokal Suku Bajo dalam pemanfaatan sumberdaya hayati laut (Studi kasus Pulau Sapeken, Kepulauan Kangean, Kabupaten Sumenep, Provinsi Jawa Timur). Departemen Sains Komunikasi dan Pengembangan Masyarakat, Fakultas Ekologi Manusia, Institut Pertanian Bogor.

Farid, M., Wulanditya, P., \& Puspitaningrum, T. D. K. (2016). Diversifikasi produk olahan kupang sebagai rintisan usaha ibu PKK Desa Bluru Kidul Sidoarjo. In G. Rudiyanto, K. Hutama, D. Asmarandani, S. K. L. Nilotama, S. Sumartono, T. Sekaryati, \& A. U. Nugroho (Eds.), Prosiding Seminar Nasional Pengabdian Kepada Masyarakat (pp. 12-20). Jakarta Barat: Pusat Studi Reka Rancang Visual dan Lingkungan Universitas Trisakti.

Gunawan, B. (2014). Proses pemberdayaan usaha kecil menengah melalui penerapan teknologi tepat guna (Studi pada dua mitra binaan pos pelayanan teknologi tepat guna karya mandiri kecamatan Tegowanu Kabupaten Grobogan). Jurusan Pendidikan Luar Sekolah, Fakultas Ilmu Pendidikan, Universitas Negeri Semarang.

Hamzah, A. (2015). Pemberdayaan ekonomi nelayan oleh PT. Karya Masyarakat Mandiri Dompet Dhuafa di Desa Tanjung Pasir Kabupaten Tangerang. UIN Syarif Hidayatullah.

Hapsati, Y. T., \& Fuad, A. D. (2017). Manajemen rantai pasokan pada masyarakat nelayan tradisional (Studi kasus pada nelayan Puger Jember). Gulawentah:Jurnal Studi Sosial, 2(2), 67-78.

Hasyim, C. L., \& Ohoiwutun, E. C. (2017). Peran komunikasi dalam pemberdayaan nelayan tradisional pada masyarakat pesisir (PMP) di Kabupaten Maluku Tenggara. Jurnal PIKOM (Penelitian Komunikasi Dan Pembangunan), 18(1), 31-42.

Hindradjit, H., Rianto, B., \& Arieffiani, D. (2017). Industrialisasi pengolahan ikan tangkap skala rumah tangga untuk meningkatkan ekonomi masyarakat pesisir di Pantai Prigi, Trenggalek. In Seminar Nasional Kelautan XII (pp. 1-12). Surabaya: Fakultas Teknik dan Ilmu Kelautan Universitas Hang Tuah.

Ibad, S. (2017). Kearifan lokal pemberdayaan masyarakat dalam pengelolaan dan pembangunan sumberdaya perikanan yang berkelanjutan (Studi Kabupaten Situbondo). Samakia: Jurnal Ilmu Perikanan, 8(1), 24-31.

Imaniar, D. (2017). Pemberdayaan masyarakat pesisir (Perempuan nelayan) melalui pemanfaatan pengolahan limbah laut dan cangkang kerang. Jurnal Humaniora, 14(2), 62-66.

Inounu, I., Martindah, E., Saptati, R. A., \& Priyanti, A. (2007). Potensi ekosistem pulau-pulau kecil dan terluar untuk pengembangan usaha sapi potong. WARTAZOA, 17(4), 156-164. Retrieved from 
http://medpub.litbang.pertanian.go.id/index.php/wartazoa/article/download/870/879

Ishak, E., \& Siang, R. D. (2013). Penguatan kapasitas kelompok nelayan wirausaha mandiri melalui transfer teknologi tepat guna. Manajemen IKM, 10(1), 9-16.

Izzaturrahim, Z., Waluti, R., Rahayuwati, R., \& Darmadji, B. N. I. (2015). Peran perempuan dalam pengadaan modal produktif untuk usaha perikanan di kampung nelayan, Tambak Lorok, Semarang. Semarang.

JICA. (2011). Perbaikan mekanisme distribusi studi melalui (Peningkatan penanganan pasca pengembangan pasar ikan panen dan fasilitas pemasaran) di Indonesia. Jakarta.

KIARA. (2015). Perempuan nelayan berhak mendapatkan perlindungan dan pemberdayaan dari negara. Jakarta.

Laksamana, H., Ro'is, F., Syahputra, D., Firdausiyah, A. S., \& Reswita, R. (2017). Pemberdayaan ibu rumah tangga nelayan melalui pelatihan diversifikasi produk perikanan dan kelembagaan di Kelurahan Malabero Kota Bengkulu. Jurnal Dharma Raflesia, 15(2), 89-94.

Laliyo, L. A. R., Salim, S., \& Pomalato, S. (2014). Rekayasa implementasi teknologi tepat guna melalui pengembangan model pembelajaran untuk menumbuhkan budaya pemanfaatan energi terbarukan pada masyarakat daerah terpencil. Gorontalo.

LPPM-UNEJ. (2017). Pengembangan industri kreatif berbasis sumberdaya hayati laut pada komunitas sentra industri kecil di wilayah pesisir pantai. Jember. https://doi.org/10.1016/S00223182(80)80003-3

Maleka, F., Monene, V., Browne, R., Kgomo, E., Ledwaba, I., Dlamini, M., \& Kgwete, N. (2007). A handbook for community development workers. Pretoria: Ministry for Public Service and Administration.

Masyhuri, M. (2013). Ekonomi syariah dalam etika pemerataan resiko. Jurnal Ekonomi Dan Pembangunan, $21(2), 125-136$.

Mooniarsih, N. T., Yacoub, R. R., \& Sanjaya, B. W. (2017). Teknologi tepat gunapengolahan limbah ikan (Kasus: Kegiatan IbM mesin pembuat tepung ikan). Jurnal Elkha, 9(1), 19. https://doi.org/10.26418/elkha.v9i1.21253

Munaf, D. R., Suseno, T., Janu, R. I., \& Badar, A. M. (2008). Peran teknologi tepat guna untuk masyarakat daerah perbatasan: Kasus propinsi Kepulauan Riau. Jurnal Sosioteknologi Edisi, 13(7), 329-333.

Napsiah, N., \& Sanityastuti, M. S. (2018). Penguatan ekonomi kelompok istri nelayan di Pantai Glagah, Kulonprogo, Yogyakarta. In Proceeding of Community Development (Vol. 2, pp. 510-519). Jakarta: Relawan Jurnal Indonesia. https://doi.org/10.30874/comdev.2018.121

Nurfadilah, T. (2016). Peranan masyarakat nelayan terhadap peningkatan ekonomi di Desa Kenje Kecamatan Campalagian Kabupaten Polewali Mandar. UIN Alauddin Makassar.

Nurwidodo, N., Rahardjanto, A., Husamah, H., Mas'odi, M., \& Hidayatullah, M. S. (2018). Model pendampingan masyarakat kepulauan berbasis rumput laut (Best practices program IbW-CSR di Kepulauan Sapeken Sumenep). Malang, Indonesia: Kota Tua.

Pandit, I. G. S. (2016). Paket teknologi tepat guna pemindangan ikan togkol. Denpasar-Bali, Indonesia: Warmadewa University Press.

Paryanto, P., Ardian, A., \& Rahmawaty, P. (2012). IbM usaha kerajinan tempurung kelapa di Kabupaten Bantul: Laporan akhir program IPTEKS bagi masyarakat. Yogyakarta.

Prakoso, J. (2013). Peranan tenaga kerja, modal, dan teknologi terhadap peningkatan pendapatan masyarakat nelayan di Desa Asemdoyong Kecamatan Taman Kabupaten Pemalang. Universitas Negeri Semarang. Retrieved from http://lib.unnes.ac.id/20041/1/7450406043.pdf 
Prastiwi, L., Sumartono, S., \& Huda, N. (2017). Pemanfaatan media pembelajaran schoology untuk proses belajar mengajar: Laporan akhir program pengabdian bagi masyarakat. Surabaya.

Pringgenies, D., Yudiati, E., Nuraeni, R. A. T., \& Susilo, E. S. (2017). Pemberdayaan kelompok wanita nelayan pesisir pantai dengan aplikasi teknologi pewarna alam limbah mangrove jadi batik di Mangkang Kecamatan Tugu Semarang. PANRITA ABDI Jurnal Pengabdian Kepada Masyarakat, 1(2), 83-89.

Rahayu, L. S. (2019). Sosial budaya suku Bajo di Pulau Sapeken Kecamatan Sapeken Kabupaten Sumenep tahun 2010-2018. Jurusan Pendidikan Ilmu Pengetahuan Sosial Fakultas Keguruan dan Ilmu Pendidikan Universitas Jember.

Rahman, A. (2018). Suku Bajo dan kemiskinan (Studi kasus kemiskinan nelayan suku Bajo di Desa Saur Saibus Kecamatan Sapeken Kabupaten Sumenep). Fakultas Ilmu Sosial dan Politik Universitas Islam Negeri Sunan Ampel Surabaya.

Rahmat, A., \& Malik, H. K. (2015). Peningkatan pendapatan keluarga miskin melalui pemberdayaan masyarakat nelayan pada sektor pengeringan ikan laut di Desa Moluo Kecamatan Kwandang Kabupaten Gorontalo Utara. Gorontalo.

Rahmatullah, R. (2016). Perilaku sosial keagamaan masyarakat nelayan di Kelurahan Baurung Kecamatan Banggae Timur Kabupaten Majene. UIN Alauddin Makassar.

Rini, D. A. S., Pratikto, W. A., \& Sambodo, K. (2015). Identifikasi potensi kawasan sumberdaya Pulau Kangean Kabupaten Sumenep Madura sebagai kawasan wisata bahari. Jurnal Kelautan, 8(2), 60-70. https://doi.org/10.21107/jk.v8i2.814

Rizal, M., Wiryawan, B., Wisudo, S. H., Solihin, I., \& Haluan, J. (2017). Kinerja kelompok usaha bersama (KUB) nelayan gillnet di Barsela Aceh. Marine Fisheries, 8(1), 73-86.

Rizal, S. (2018). Analisis ekonomi usaha agroindustri abon berbasis ikan laut di Kota Mataram. Mataram, West Nusa Tenggara, Indonesia.

Rosni, R. (2017). Analisis tingkat kesejahteraan masyarakat nelayan di Desa Dhari Kecamatan Talawi Kabupaten Butabara. Jurnal Geografi, 9(1), 53-66.

S.Politon, R., Kassa, S., \& Effendy, E. (2018). Maksimisasi pendapatan abon ikan pada CV. Duta Agro Lestari di Kota Palu Sulawesi Tengah. J. Agroland, 25(2), 145-153.

Sabarudin, S., Suyatno, A., \& Su'i, M. (2017). Optimalisasi kinerja mesin roll plate terhadap produktifitas mesin-mesin tepat guna. In SENASPRO 2 (pp. 373-381). Malang: DPPM UMM dan UMM Press.

Satriyati, E., \& Rahayu, D. (2009). Upaya pengentasan kemiskinan di Madura sebagai model pengembangan tanggung jawab sosial. Masyarakat, Kebudayaan Dan Politik, 23(2), 119-129. Retrieved from http://journal.unair.ac.id/MKP@upaya-pengentasan-kemiskinan-di-madurasebagai-model-pengembangan-tanggung-jawab-sosial-article-4106-media-15-category-8.html

Siburian, P., \& Batubara, H. (2017). Upaya peningkatan ekonomi desa melalui penerapan teknologi tepat guna. In PROSIDING SEMINAR NASIONAL PENGABDIAN MASYARAKAT (pp. 1-22). Medan: LPM UNIMED.

Suhendar, S., Ramdhan, B., \& Sudarma, A. (2019). Program penerapan teknologi tepat guna implementasi ASTER (Alat silase terkompartemen) untuk peternak domba di Wilayah Kadudampit Kabupaten Sukabumi. Sarwahita, 15(01), 32-40. https://doi.org/10.21009/sarwahita.151.04

Sukandar, S., Handayani, M., Dewi, C. S. U., Harsindhi, C. J., Maulana, A. W., Supriyadi, S., \& Bahroni, A. (2016). Profil desa pesisir provinsi Jawa Timur Volume 3 (Kepulauan Madura) (Vol. 3). Surabaya: Dinas Perikanan Dan Kelautan Provinsi Jawa Timur. 
Surjanti, J., \& Nuswantara, D. A. (2016). Pemberdayaan sociopreneurship masyarakat nelayan (Studi pada UKM “Crispy Ikan Sunduk” Kabupaten Lamongan). In I. W. Susila, S. Suroto, \& T. Tukiran (Eds.), Prosiding Seminar Nasional Hasil Penelitian dan Pengabdian Kepada Masyarakat. Surabaya: FMIPA dan LPPM UNESA Surabaya.

Susanto, H. (2017). Desain dan manufaktur teknologi tepat guna pedesaan. Meulaboh: Universitas Teuku Umar.

Sutanto, A., Effiandi, N., \& Alfian, A. (2014). Rancangan teknologi tepat guna untuk pembuatan cakram pemutar turbin aliran silang skala bengkel. TeknikA, 21(1), 35-42.

Sutanto, M. A., Riyanto, B., \& Yuwono, E. C. (2013). Perancangan promosi untuk menunjang potensi wisata bahari Kepulauan Kangean, Kabupaten Sumenep, Jawa Timur. Jurnal DKV Adiwarna, 1(2), 1-20. Retrieved from http://publication.petra.ac.id/index.php/dkv/article/view/694/603

Suteja, Y., Dirgayusa, I. G. N. P., Widiastuti, W., \& Putra, I. D. N. N. (2019). Pelatihan penggunaan fishfinder bagi nelayan Kedongan guna meningkatkan produksi perikanan. Buletin Udayana Mengabdi, 18(1), 143-148.

Sutrisno, E. (2012). Implementasi pengelolaan sumber daya pesisir berbasis pengelolaan wilayah pesisir secara terpadu untuk kesejahteraan nelayan (Studi di perdesaan nelayan Cangkol Kelurahan Lemahwungkuk Kecamatan Lemahwungkuk Kota Cirebon). Jurnal Dinamika Hukum, 14(1), 1-12.

Triadiyatma, A. (2016). Model penyelesaian konflik nelayan berbasis kearifan lokal sebagai modal sosial di Kecamatan Lekok Kabupaten Pasuruan. Universitas Airlangga Surabaya.

Wardhani, R. M., Rekyani, I. P., \& Indayati, I. (2010). Peningkatan pendapatan masyarakat melalui diversivikasi produk olahan ikan (Abon tuna, dendeng lemuru, krupuk rambak tuna). Agritek, 11(2), 54-64.

Warnaen, A., Cangara, H., \& Bulkis, S. (2013). Faktor-faktor yang menghambat inovasi pada komunitas petani dan nelayan dalam meningkatkan kesejahteraan masyarakat di Kabupaten Takalar. Jurnal Komunikasi KAREBA, 2(3), 241-250.

Witarsa, W. (2015). Model pengembangan ekonomi masyarakat pesisir berbasis co-management sumberdaya perikanan di Kabupaten Pontianak. Jurnal Economia, 11(1), 26. https://doi.org/10.21831/economia.v11i1.7752

World Health Organization. (2017). WHO strategic communications framework for effective communications. Geneva: Department of Communications World Health Organization. Retrieved from https://www.who.int/mediacentre/communication-framework.pdf 